\title{
PARENTERAL IRON SUCROSE VERSUS DOUBLING DOSE ORAL FERROUS FUMARATE FOR TREATMENT OF IRON DEFICIENCY ANEMIA IN PREGNANCY
}

\author{
By
Ayman A. El-Wahed, Mazen A. El-Zahry, Mohamed T. Ismail and Ibrahim A Abousekein \\ Department of Obstetrics and Gynecology, Faculty of Medicine, Al-Azhar University \\ Corresponding author: Ayman A. El-Wahed,
}

Mobile: 01200202224, E-mail: ayman19847666@gmail.com

\begin{abstract}
Background: Iron deficiency anemia (IDA) is considered one of the leading problems in pregnancy.

Objective: To compare the impact of doubling the standard dose of oral iron ferrous fumarate versus I.V iron sucrose to improve $\mathrm{Hb}$, and S.ferritin levels in pregnancy for those women suffering from IDA between fourteen and thirty four week of gestation.

Patients and Methods: This was a controlled randomized clinical trial done over five hundred women with gestational age between fourteen and thirty four weeks in the department of Obstetrics and Gynecology at AlSayd Galal Hospital, from June 2019 to October 2020. All pregnant women included were counselled with an informed consent obtained before beginning of this study. Pregnant women were randomly divided into 2 equal groups: Group A for ferrous fumarate oral iron therapy while Group B for parenteral iron sucrose therapy. Pregnant women precipitating in this study were asked for medical history in details. Also they had undergone clinical examination and laboratory investigations including CBC and S. ferritin pretreatment and post treatment.

Results: The parenteral iron sucrose had more significant results than doubling the dose of ferrous fumarate oral iron treating IDA women during pregnancy. Few side effects were detected, and thus, it considered as a useful and alternative formulation in treatment of IDA. So, i.v iron sucrose infusion was more favorable for doubling the standard dose of ferrous fumarate as anaphylaxis risk was minimal. On the contrary, noncompliance to ferrous fumarate oral iron increased with doubling the dose. Parental iron showed a faster and more significant response than that for oral iron because of increased amount of iron available for $\mathrm{Hb}$ synthesis in the bone marrow when treating women using I.V iron therapy.
\end{abstract}

Conclusion: Parenteral iron sucrose has better results than that when using double the standard dose oral iron ferrous fumarate treating IDA in women during pregnancy as I.V iron improves the concentration of $\mathrm{Hb}$ and S.ferritin more significant than oral iron therapy.

Key words: parenteral iron sucrose, doubling dose, oral ferrous fumarate, treatment, iron deficiency anemia, pregnancy.

\section{INTRODUCTION}

Pregnancy anemia can cause severe adverse outcomes for the mother, the fetus or for both. Maternal adverse outcomes such as postpartum hemorrhage, sepsis, pre-eclampsia, preterm labor and 
increased possibility of blood transfusion, while adverse fetal outcome may include high fetal mortality rate at the 3rd trimester. Also, IDA can affect the motor and mental development of children and adolescents (Saeed et al., 2018).

Routine supplementation of iron is strongly advised during pregnancy as most of pregnant women do not have adequate iron stores. WHO states that $38.2 \%$ of women in pregnancy suffer from anemia and about half of them suffer from IDA (WHO, 2015).

Singleton pregnancy maternal requirements of iron are about $1000 \mathrm{mg}$ during term pregnancy that will be divided as follows: $300 \mathrm{mg}$ for both fetal and placental requirements and $500 \mathrm{mg}$ for maternal RBCs expansion. The rest of iron will be lost through gut, skin and urine extraction (Shinar et al., 2017).

Diagnosis of IDA in pregnancy is strongly advised to be as early as possible as it can help early management. IDA has certain characteristics which include decreased concentrations of $\mathrm{Hb}$, decreased number of RBCs, total S.iron and S. ferritin low levels (Maria et al., 2018).

Experts recommend increased intake of O.I from 15 up to $30 \mathrm{mg}$ elemental iron during pregnancy. An amount readily met by most prenatal vitamins formulations used (Cantor et al., 2015).

Prophylaxis and treatment of mild form of IDA needs the use of O.I therapy as a 1 st choice, while in moderate and severe forms of IDA pregnant women, oral therapy needs a prolonged time. As a result of this, treatment whether by I.V. iron or blood transfusion is related to patient condition (degree of anemia, hemodynamic status, and period of gestation) should be recommended in women suffering from moderate or severe anemia during pregnancy (Kriplani et al., 2013).

Dietary habits changes alone are not adequate to help IDA correction so iron supplementions are necessary. Ferrous iron salt preparations of choice include ferrous fumarate O.I, ferrous sulphate O.I and ferrous gluconate O.I. Elemental iron amounts which comes out of this iron salts are different. O.I recommended dose in patients suffering from IDA should be $100 \mathrm{mg}$ up to $200 \mathrm{mg}$. Using combination of O.I ferrous fumarate with folic acid preparations should be adviced (Pavord et al., 2012).

Several adverse effects can result from using ferrous fumarate O.I therapy in treatment of IDA including gastric irritation, diarrhea, constipation, vomiting and abdominal pain, which can be treated by intake of O.I tablets after meals, but iron absorption of O.I therapy will decrease leading to decreased effectiveness of treatment (Di Renzo et al., 2015).

I.V. iron sucrose is one of preparations which is associated with higher availability for erythropoiesis than that of other I.V. preparations like iron dextran (Cançado and Muñoz, 2011). However, its use is limited by the total dose that can be administered in one infusion. The newer preparations, iron III carboxymaltose or iron III isomaltoside, aims to solve this problem, with single dose administration in an hour or less (Gozzard, 2011).

This study aimed to compare the impact of doubling O.I ferrous fumarate dose versus parenteral iron sucrose 
infusion in improving $\mathrm{Hb}$ and S.ferritin outcome in women suffering from IDA in pregnancy at gestational age of fourteen up to thirty four weeks.

\section{PATIENTS AND METHODS}

This controlled randomized clinical trial was conducted at The Department of Obstetrics and Gynecology, Al-Sayd Galal hospital from June 2019 to October 2020. Five hundred pregnant women with gestational age between fourteen up to thirty four weeks were involved in the study with an informed consent asked for all women precipitating.

All involved pregnant women undergone both general and abdominal examination. BMI calculation was done by dividing patient weight in $\mathrm{kg}$ by her height in square meters. Also, serial obstetric ultrasound examination was done for every woman.

The study inclusion criteria for precipitating women was $\mathrm{Hb}$ concentration 70 up to $105 \mathrm{~g} / \mathrm{L}$, S.ferritin less than $15 \mathrm{ng} / \mathrm{ml}$, ages from twenty to fourty years old, singleton pregnancy and BMI $18-25$.

On the other hand multifetal gestations, active vaginal bleeding, women suffering from hyperemesis gravidarium in the past twenty weeks of pregnancy, malabsorption diseases (inflammatory bowel diseases such as crohns disease and ulcerative colitis), and pregnant women suffering from chronic diseases causing anemia, hemoglobinpathies, and chronic renal diseases were excluded from the study.

Patients were randomly divided into 2 equal groups: Group A for oral iron
(O.I) therapy and Group B for parenteral (I.V) iron therapy.

The following measurements were recorded: $\mathrm{HB} \%, \mathrm{CBC}$, and S.ferritin. Four weeks later, $\mathrm{Hb}$ and S.ferritin were repeated for both groups.

In the oral (O.I) iron therapy group, patients received double recommended dose of O.I ferrous fumarate (two capsules) each capsule contained $305 \mathrm{mg}$ iron salt which subsequently gave $100 \mathrm{mg}$ elemental iron daily for four weeks. This treatment was associated with 500 ug of folic acid supplementations daily. All participant patients were asked to take two capsules 12 hours apart at least two hours after eating dairy products or one hour before meals with vitamin $\mathrm{C}$ source such as orange Juice to increase iron absorption. Women were asked to give back empty iron and folic acid packs during follow up visits. Treatment compliance was noted carefully. Adverse effect symptoms like vomiting, diarrhea, or constipation was recorded. No other medications affecting iron absorption was taken at the same time.

In the parenteral (I.V) iron group, total iron sucrose dose needed was calculated by using this formula:

Total dose needed =weight in $\mathrm{kg} x$ (target $\mathrm{Hb}$ in $\mathrm{g} / \mathrm{L}$ - Actual $\mathrm{Hb}$ in $\mathrm{g} / \mathrm{L}$ ) $\mathrm{x}$ $0.24+500 \mathrm{mg}$. rounded up to nearest multiple of $100 \mathrm{mg}$.

Parenteral iron sucrose was given as $200 \mathrm{mg}$ of iron sucrose in $100 \mathrm{ml} 0.9 \%$ sodium chloride solution infusion over 30 minutes in three separated doses day after day with maximum dose of $600 \mathrm{mg}$ in the week. Folic acid supplementation in 500 ug per dose was given once daily for four 
weeks (study time) to eliminate folic acid deficiency effect on the results. Additional oral iron tablets for the parenteral iron group were prevented during the study time.

\section{Statistical analysis:}

Recorded data were analyzed using the statistical package for the social sciences, version 20.0 (SPSS Inc., Chicago, Illinois, USA). Quantitative data were expressed as mean \pm standard deviation (SD). Qualitative data were expressed as frequency and percentage.

The following tests were done: Independent-samples t-test of significance was used when comparing between two means. Paired sample t-test of significance was used when comparing between related samples. Mann Whitney U test: for two-group comparisons in non-parametric data. Comparison between two related samples for non-parametric data using Wilcoxon Rank Sum test. Chi-square ( $\square 2$ ) test of significance was used in order to compare proportions between qualitative parameters. The confidence interval was set to $95 \%$ and the margin of error accepted was set to $5 \%$. So, P-value $<0.05$ was considered significant.

\section{RESULTS}

No statistically significant differences were found between both groups according to their demographic data regarding age, parity, BMI and GA (Table 1).

Table (1): Comparison between Group A: Oral Iron (O.I) therapy and Group B: Parenteral Iron therapy according to demographic data

\begin{tabular}{|c|c|c|c|}
\hline $\begin{array}{l}\text { Group } \\
\text { Demographic data }\end{array}$ & $\begin{array}{l}\text { Group A: Oral } \\
\text { Iron }(n=234) \\
\end{array}$ & $\begin{array}{c}\text { Group B: Parenteral } \\
\text { Iron }(\mathbf{n}=\mathbf{2 3 7})\end{array}$ & $\begin{array}{c}\text { p- } \\
\text { value }\end{array}$ \\
\hline \multicolumn{4}{|l|}{ Age (years) } \\
\hline Range & $20-40$ & $20-40$ & \multirow{2}{*}{0.339} \\
\hline Mean \pm SD & $29.15 \pm 3.51$ & $28.83 \pm 3.74$ & \\
\hline \multicolumn{4}{|l|}{ Parity } \\
\hline Range & $0-3$ & $0-3$ & \multirow{2}{*}{0.654} \\
\hline Median (IQR) & $2(1)$ & $2(1)$ & \\
\hline $\mathbf{P 0} \mathbf{0}^{\mp}$ & $41(17.5 \%)$ & $55(23.5 \%)$ & \multirow{4}{*}{0.232} \\
\hline P1 & $55(23.5 \%)$ & $47(20.1 \%)$ & \\
\hline $\mathbf{P 2}$ & $76(32.5 \%)$ & $64(27.4 \%)$ & \\
\hline $\mathbf{P 3}$ & $62(26.5 \%)$ & $71(30.3 \%)$ & \\
\hline \multicolumn{4}{|l|}{ BMI [wt/(ht)^2] } \\
\hline Range & $18-25$ & $18-25$ & \multirow{2}{*}{0.074} \\
\hline Mean \pm SD & $21.76 \pm 2.43$ & $22.07 \pm 1.30$ & \\
\hline \multicolumn{4}{|l|}{ GA (wks). } \\
\hline Range & $14-34$ & $14-34$ & \multirow{2}{*}{0.260} \\
\hline Mean \pm SD & $27.19 \pm 2.01$ & $26.97 \pm 2.22$ & \\
\hline
\end{tabular}

Using: t-Independent Sample t-test; $₫$ z-Mann-Whitney test; ¥ Chi-square test, p-value $>0.05 \mathrm{NS}$ 
There was no significant difference statistically between both groups according to their pre MCV, MCT and MCHC, while significant statistically mean increase in Parenteral Iron therapy compared to (O.I) Oral Iron therapy is noticed according to their laboratory data regarding post $\mathrm{Hb}, \mathrm{MCV}$ and $\mathrm{HCT}$, MCHC, while s.Ferritin significant higher in Group B (Table 2).

Table (2): Comparison between Group A: Oral Iron (O.I) therapy and Group B: Parenteral Iron therapy according to pre and post laboratory data

\begin{tabular}{|c|c|c|c|}
\hline $\begin{array}{l}\text { Group } \\
\text { Laboratory data }\end{array}$ & $\begin{array}{l}\text { Group A: } \\
\text { Oral Iron } \\
(\mathbf{n}=\mathbf{2 3 4}) \\
\end{array}$ & $\begin{array}{c}\text { Group B: } \\
\text { Parenteral Iron } \\
(\mathbf{n}=\mathbf{2 3 7}) \\
\end{array}$ & p-value \\
\hline \multicolumn{4}{|l|}{ Pre Laboratory } \\
\hline \multicolumn{4}{|l|}{ Hb. (mg/dl) } \\
\hline Range & $7.14-10.71$ & $7.14-10.2$ & 0.443 \\
\hline Mean \pm SD & $8.70 \pm 1.17$ & $8.78 \pm 1.09$ & \\
\hline \multicolumn{4}{|l|}{ MCV } \\
\hline Range & $62-81$ & $61-83$ & 0.056 \\
\hline Mean \pm SD & $70.48 \pm 5.25$ & $71.53 \pm 6.56$ & \\
\hline \multicolumn{4}{|l|}{ HCT } \\
\hline Range & $17.34-22.24$ & $17.44-22.13$ & 0.134 \\
\hline Mean \pm SD & $20.30 \pm 1.50$ & $20.52 \pm 1.68$ & \\
\hline \multicolumn{4}{|l|}{ MCHC } \\
\hline Range & $13-30$ & $13-29$ & 0.136 \\
\hline Mean \pm SD & $21.82 \pm 4.96$ & $22.52 \pm 5.20$ & \\
\hline \multicolumn{4}{|l|}{ Serum Ferritin } \\
\hline Range & $7-14$ & $8-14$ & 0.174 \\
\hline Median (IQR) & $12(3)$ & $12(2)$ & \\
\hline \multicolumn{4}{|l|}{ Post Laboratory } \\
\hline Hemoglobin & $9.80 \pm 1.23$ & $10.97 \pm 1.88$ & 0.025 \\
\hline $\mathrm{MCV}$ & $74.05 \pm 8.44$ & $80.50 \pm 5.96$ & 0.008 \\
\hline HCT & $25.49 \pm 1.74$ & $28.47 \pm 1.62$ & 0.009 \\
\hline $\mathrm{MCHC}$ & $23.99 \pm 5.57$ & $26.33 \pm 4.98$ & 0.029 \\
\hline s.Ferritin: & Median 39 (IQR: 15) & Median 83 (IQR: 32) & $<0.001$ \\
\hline
\end{tabular}

Using: t-Independent Sample t-test; $\$$ Mann-Whitney test

There was a statistically significant mean increase in post-treatment and pretreatment according to their laboratory data regarding $\mathrm{Hb}, \mathrm{MCV}, \mathrm{HCT}$, MCHC and Ferritin (Table 3). 
Table (3): Comparison between pre-treatment and post-treatment according to laboratory data in Group A: oral (O.I) iron therapy

\begin{tabular}{|c|c|c|c|c|c|}
\hline $\begin{array}{l}\text { O.I Group } \\
\text { Laboratory data }\end{array}$ & $\begin{array}{c}\text { Pre- } \\
\text { Treatment }\end{array}$ & $\begin{array}{c}\text { Post- } \\
\text { Treatment }\end{array}$ & Mean Diff. & Change\% & $\begin{array}{c}\text { p- } \\
\text { value }\end{array}$ \\
\hline Hemoglobin & $8.70 \pm 1.17$ & $9.80 \pm 1.23$ & $1.10 \pm 0.37$ & $12.64 \pm 4.30$ & 0.006 \\
\hline $\mathrm{MCV}$ & $70.48 \pm 5.25$ & $74.05 \pm 8.44$ & $3.57 \pm 1.21$ & $5.07 \pm 1.72$ & 0.041 \\
\hline HCT & $20.30 \pm 1.50$ & $25.49 \pm 1.74$ & $5.19 \pm 1.76$ & $25.57 \pm 8.69$ & 0.012 \\
\hline $\mathrm{MCHC}$ & $21.82 \pm 4.96$ & $23.99 \pm 5.57$ & $2.17 \pm 0.74$ & $9.95 \pm 3.38$ & 0.042 \\
\hline Ferritin $^{€}$ & $\begin{array}{l}\text { Median } 12 \\
\text { (IQR: 2) }\end{array}$ & $\begin{array}{l}\text { Median } 39 \\
\text { (IQR: 15) }\end{array}$ & $\begin{array}{l}\text { Median } 27 \\
\text { (IQR: 9) }\end{array}$ & $\begin{array}{c}\text { Median } 229 \\
\text { (IQR 78) }\end{array}$ & $<0.001$ \\
\hline
\end{tabular}

Using: Paired Sample t-test; $€ W$ ilcoxon test

*p-value $<0.05 \mathrm{~S}$; **p-value $<0.001 \mathrm{HS}$

There was a highly statistically significant mean increase in posttreatment and pre-treatment according to their laboratory data regarding $\mathrm{Hb}, \mathrm{MCV}$, HCT, MCHC and Ferritin (Table 4).

Table (4): Comparison between pre-treatment and post-treatment according to CBC in Group B: Parenteral Iron therapy

\begin{tabular}{|c|c|c|c|c|c|}
\hline $\begin{array}{c}\text { Parenteral iron } \\
\text { group } \\
\text { Laboratory data }\end{array}$ & $\begin{array}{c}\text { Pre- } \\
\text { Treatment }\end{array}$ & $\begin{array}{c}\text { Post- } \\
\text { Treatment }\end{array}$ & $\begin{array}{c}\text { Mean } \\
\text { Diff. }\end{array}$ & Change\% & p-value \\
\hline Hemoglobin & $8.78 \pm 1.09$ & $10.97 \pm 1.88$ & $2.19 \pm 0.74$ & $24.94 \pm 8.48$ & $<\mathbf{0 . 0 0 1}$ \\
\hline MCV & $71.53 \pm 6.56$ & $80.50 \pm 5.96$ & $8.97 \pm 3.05$ & $12.54 \pm 4.26$ & $<\mathbf{0 . 0 0 1}$ \\
\hline HCT & $20.52 \pm 1.68$ & $28.47 \pm 1.62$ & $7.95 \pm 2.70$ & $38.74 \pm 13.17$ & $<\mathbf{0 . 0 0 1}$ \\
\hline MCHC & $22.52 \pm 5.20$ & $26.33 \pm 4.98$ & $3.81 \pm 1.30$ & $16.92 \pm 5.75$ & $<\mathbf{0 . 0 0 1}$ \\
\hline Ferritin & $\begin{array}{c}\text { Median } 12 \\
\text { (IQR: } 2)\end{array}$ & $\begin{array}{c}\text { Median } 83 \\
\text { (IQR: } 32)\end{array}$ & $\begin{array}{c}\text { Median } 76 \\
\text { (IQR: } 26)\end{array}$ & $\begin{array}{c}\text { Median } 622 \\
\text { (IQR: } 211)\end{array}$ & $<\mathbf{0 . 0 0 1}$ \\
\hline
\end{tabular}

Using: Paired Sample t-test; €Wilcoxon test

**p-value $<0.001 \mathrm{HS}$

There was a statistically significant higher mean change in Parenteral Iron therapy compared to Oral Iron (O.I) therapy according to their laboratory data regarding Hemoglobin, $\mathrm{MCV}$ and $\mathrm{HCT}$, MCHC, while S.Ferritin significant higher in Group B (Table 5). 
Table (5): Comparison between Group A: Oral Iron (O.I) therapy and Group B: Parenteral Iron therapy according to change between pre and posttreatment at laboratory data

\begin{tabular}{|c|c|c|c|}
\hline Laboratory data & $\begin{array}{l}\text { Group A: } \\
\text { Oral Iron } \\
(\mathbf{n}=\mathbf{2 3 4})\end{array}$ & $\begin{array}{c}\text { Group B: } \\
\text { Parenteral Iron } \\
(\mathbf{n}=\mathbf{2 3 7})\end{array}$ & p-value \\
\hline \multicolumn{4}{|l|}{ Hemoglobin } \\
\hline Diff. Median (IQR) & $1(0)$ & $2(1)$ & \multirow{2}{*}{0.002} \\
\hline Change\% Median (IQR) & $13(4)$ & $25(8)$ & \\
\hline \multicolumn{4}{|l|}{ MCV } \\
\hline Diff. Median (IQR) & $4(1)$ & $9(3)$ & \multirow{2}{*}{0.002} \\
\hline Change\% Median (IQR) & $5(2)$ & $13(4)$ & \\
\hline \multicolumn{4}{|l|}{ HCT } \\
\hline Diff. Median (IQR) & $5(2)$ & $8(3)$ & \multirow{2}{*}{0.021} \\
\hline Change\% Median (IQR) & $26(9)$ & $39(13)$ & \\
\hline \multicolumn{4}{|l|}{ MCHC } \\
\hline Diff. Median (IQR) & $2(1)$ & $4(1)$ & \multirow{2}{*}{0.005} \\
\hline Change\% Median (IQR) & $10(3)$ & $17(6)$ & \\
\hline \multicolumn{4}{|l|}{ Ferritin } \\
\hline Diff. Median (IQR) & $27(9)$ & $76(26)$ & \multirow{2}{*}{$<0.001$} \\
\hline Change\% Median (IQR) & $229(78)$ & $622(211)$ & \\
\hline
\end{tabular}

Using: Mann-Whitney test

There was a statistically significant higher nausea, vomiting and gastritis in oral iron therapy group compared to parenteral iron therapy group. Also, a statistically significant higher anaphylactic reaction and local thrombophlebitis in parenteral iron was present compared to oral iron according to side effects (Table 6).

Table (6): Comparison between Group A: Oral Iron (O.I) therapy and Group B: Parenteral Iron therapy according to their side effects

\begin{tabular}{|l|c|c|c|}
\hline Groups & $\begin{array}{c}\text { Group A: } \\
\text { Oral Iron } \\
(\mathbf{n = 2 3 4 )}\end{array}$ & $\begin{array}{c}\text { Group B: } \\
\text { Parenteral Iron } \\
(\mathbf{n = 2 3 7})\end{array}$ & $\begin{array}{c}\text { p- } \\
\text { value }\end{array}$ \\
\hline Nausea \& vomiting & $17(7.3 \%)$ & $5(2.1 \%)$ & $\mathbf{0 . 0 1 5}$ \\
\hline Gastritis & $37(15.8 \%)$ & $7(3.0 \%)$ & $<\mathbf{0 . 0 0 1}$ \\
\hline $\begin{array}{l}\text { Anaphylacticreaction } \\
\text { symptoms }\end{array}$ & $2(0.9 \%)$ & $12(5.1 \%)$ & $\mathbf{0 . 0 1 6}$ \\
\hline Local thrombophlebitis & $0(0.0 \%)$ & $17(7.3 \%)$ & $<\mathbf{0 . 0 0 1}$ \\
\hline
\end{tabular}

Using: Chi-square test

\section{DISCUSSION}

Pregnancy is accompanied with physiological hemodilution which peaks in gestational age 20-24 weeks which leads to $\mathrm{Hb}$ level differences through trimesters (Di Renzo et al., 2015).

Serum ferritin level can be used as a diagnostic investigation of IDA and to reflect iron stores condition as bone 
marrow sampling isn't practical to measure iron stores status in the body (Daru et al., 2017).

This study proved that the I.V. iron sucrose therapy was much more effective than the doubling O.I dose of ferrous fumarate therapy in management of severe IDA.

The results of the present study were in agreement with those done by Bhavi and Jaju (2017) as they conducted a study comparing aspects of efficacy, safety and compliance of patients for O.I ferrous fumarate therapy (group A), and I.V iron sucrose therapy (group B) in treatment of IDA for anemic women during pregnancy.

Serum ferritin levels showed a significant difference in the same study after four weeks of treatment in both the groups. In a study done by Neeru et al. (2012) comparing the efficacy, safety and compliance of O.I therapy (ferrous fumarate) with that of I.V iron sucrose therapy and their effect on $\mathrm{Hb}$ and $\mathrm{S}$. ferritin levels.

Definitive and comparable increase in $\mathrm{Hb}$ and all the blood values (hematocrit, $\mathrm{MCH}, \mathrm{MCHC}, \mathrm{MCV}$, Serum iron and TIBC) were observed. S.ferritin showed statistically significant increase after parenteral iron treatment in comparison to O.I treatment.

A study done by Radhika et al. (2019), showed that O.I was accompanied with significant G.I.T side effects and noncompliance to O.I treatment which led to failure treatment strategies.

On the contarary, Bhavi and Jaju (2017) had a study as they used ferrous fumarate O.I for treatment of IDA in pregnant women at dose $200 \mathrm{mg}$ daily.
They reported good compliance of pregnant patients receiving oral treatment. However he, they thought that gastrointestinal symptoms are dose related as these symptoms are common by increasing the doses and also affected by the formulation of O.I.

Our study showed that during pregnancy in the parentral group who were treated with I.V iron sucrose, reported local thrombophlebitis. Some pregnant women developed irrelevant complains like nausea and vomiting for one time others suffered from gastritis they were treated and I.V iron sucrose doses were completed.

I.V iron therapy is considered a safe alternative since it decreases blood transfusion for treatment of IDA. In addition, side effects related to supplementation of iron through this route, such as anaphylactic shock, febrile and hemolytic reactions, infections (hepatitis B, C, HIV, protozoan and bacterial) alloimmunization and graft versus host disease are very rare.

Our study was in agreement with study done by Neogi et al. (2019) in a study done on women during pregnancy aged above 18 years old, with gestational age of twenty up to twenty eight weeks with a $\mathrm{Hb}$ concentration of five to eight $\mathrm{mg} / \mathrm{dL}$, or at twenty nine up to thirty two weeks of gestation with a $\mathrm{Hb}$ concentration of five to nine $\mathrm{mg} / \mathrm{dL}$. Patients showed no serious adverse effects related to the trial procedures or the interventions as assessment was done by the trial investigators, ethics committees, and regulatory body; which ensures the safety of i.v. iron sucrose therapy. 
Another study was in agreement with our study done by Kriplani et al. (2013) in which pregnant woman was recruited for I.V iron sucrose complex at doses of 200 mg twice weekly. There were no major side effects and no allergic or anaphylactic reaction.

\section{CONCLUSION}

The use of I.V. iron sucrose for treatment of IDA in pregnancy was better than the use of double dose oral ferrous fumarate as I.v iron increase the concentration of $\mathrm{Hb}$ and $\mathrm{S}$. ferritin more significant than oral iron.

\section{REFERENCES}

1. Bhavi $S$ and Jaju P. (2017): Intravenous iron sucrose $\mathrm{v} / \mathrm{s}$ oral furrous fumarate for treatment of anemia in pregnancy. BMC pregnancy and children, 17:137-141.

2. Cançado RD and Muñoz M. (2011): Intravenous iron therapy: how far have we come? Revista brasileira de hematologia e hemoterapia, 33(6):461 469.

3. Cantor AG, Bougatsos C, Dana T, Blazina I and McDonagh M. (2015): Routine iron supplementation and screening for iron deficiency anemia in pregnancy: a systematic review for the U.S. preventive services task force. Ann intern Med., 162(8): 566-576.

4. Daru J, Colman K, Stanworth SJ, De La Salle B, Wood EM and Pasricha SR. (2017): Serum ferritin as an indicator of iron status: what do we need to know?. The American journal of clinical nutrition, 106 (suppl_6): 1634S-9S.
5. Di Renzo GC, Spano F, Giardina I, Brillo E, Clerici G and Roura LC. (2015): Iron deficiency anemia in pregnancy. Women's Health, 11(6):891-900.

6. Gozzard D. (2011): When is highdose intravenous iron repletion needed? Assessing new treatment options. Drug Design, Development and Therapy, 5: 51-60.

7. Kriplani A, Mahey R, Dash BB, Kulshreshta V, Agarwal $\mathbf{N}$ and Bhatla N. (2013): Intravenous Iron sucrose therapy for moderate to severe anemia in pregnancy. Indian $\mathrm{J}$ Med Res., 138(1): 78-82.

8. Maria SL, Luigi R, Antimo C, Maria PC, Rosalba $\mathbf{P}$ and Piera V. (2018): Efficacy of lactoferrin oral administration in the treatment of anemia and anemia of inflammation in pregnant and non-pregnant women: An interventional study. Frontiers in immunology, 9(13): 21-23.

9. Neeru $S$, Sreekumaran $N$ and Rai $L$. (2012): Iron Sucrose Versus Oral Iron Therapy in Pregnancy Anemia; Indian J Community Med., 37(4): 214-218.

10. Neogi SB, Devasenapathy N, Singh R, Bhushan H, Shah D, Divakar H, Zodpey S, Malik S, Nanda S, Mittal $P$ and Batra A. (2019): Safety and effectiveness of intravenous iron sucrose versus standard oral iron therapy in pregnant women with moderate-to-severe anaemia in India: a multicentre, open-label, phase 3, randomised, controlled trial. The Lancet Global Health, 7(12):e1706-16.

11. Pavord S, Myers B, Robinson S, Allard S, Strong $\mathbf{J}$ and 
Oppenheimer C. (2012): British Committee for Standards in Haematology. UK guidelines on the management of iron deficiency in pregnancy. Br J Haematol., 156:588600.

12. Radhika A, Kandala A, Perumal V, Sinha $A$ and Sriganesh V. (2019): Parenteral Versus Oral Iron for Treatment of Iron Deficiency Anaemia during Pregnancy and post-partum: A Systematic Review: Journal of Obstetrics and Gynecology of India, 69(1):13-24.

13. Saeed B, Abdullah AY and Abdulrhman T. (2018): Association between iron deficiency anemia and clinical features among pregnant
Women: a prospective cohort study. Journal of Blood Medicine, 163-169.

14. Shinar S, Skornick-Rapaport $A$ and Maslovitz S. (2017): Iron supplementation in singleton pregnancy: Is there a benefit of doubling the dose of elemental iron in iron deficient pregnant women? A randomized controlled trial. Journal of Perinatology, 37: 782-786.

15. World Health Organization (WHO) (2015): The global prevalence of anemia in (2011). WHO: Geneva. 


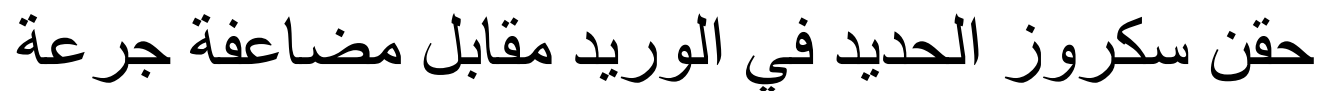

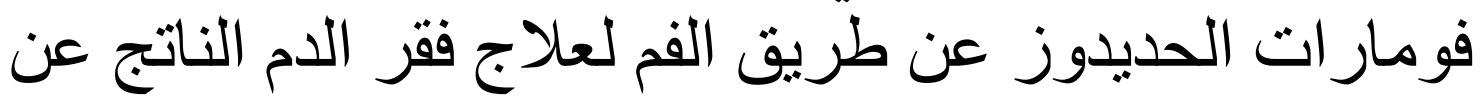

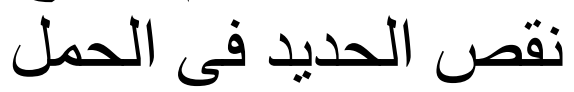

أيمن عادل دسوقى عبد الواحد، مازن عبد الرؤوف الزهرى، محمد طاهر محمد إسماعيل، إبراهيم عبد الحميد أبو سكين

قسم التوليد وأمراض النساء، كلية الطب، جامعة الأزهر

E-mail: ayman19847666@gmail.com

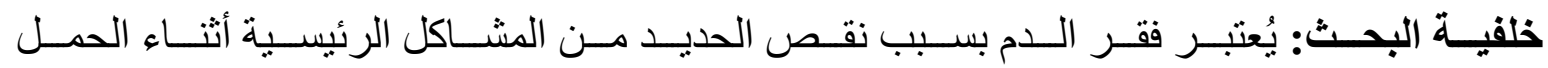

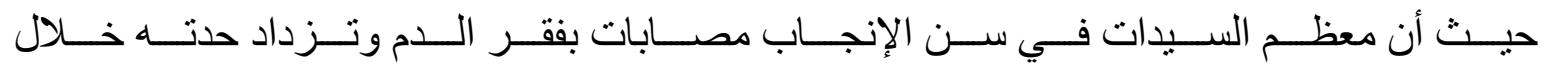
نالك الفترة.

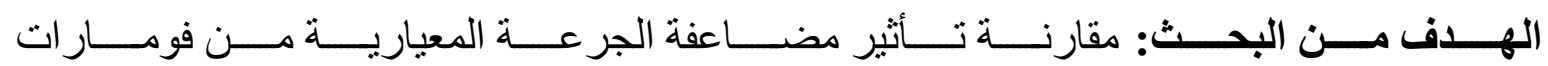

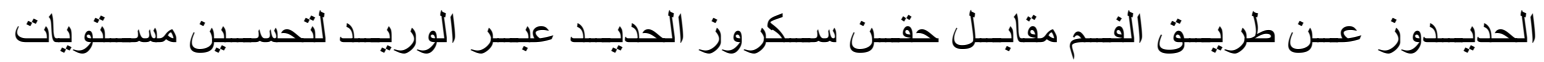

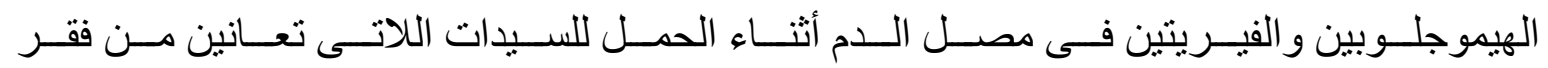
الدم بسبب نقص الحديد بين أربعة عثر و أربعة وثلاثين أسبوعًا من الحمل.

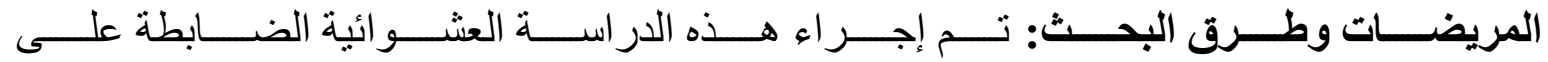

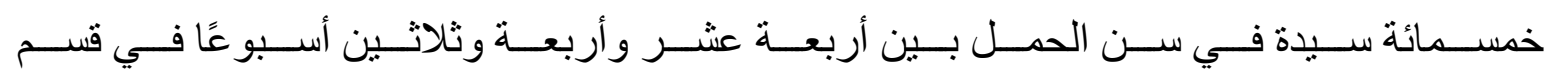

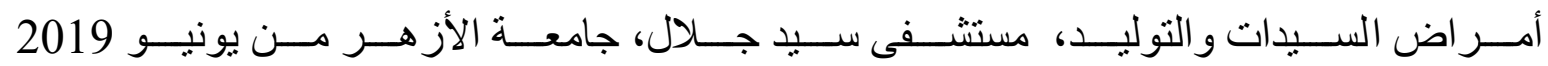

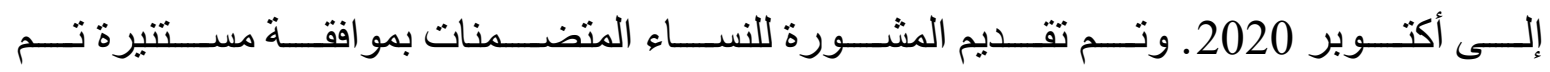

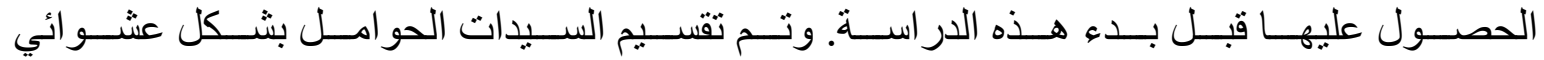

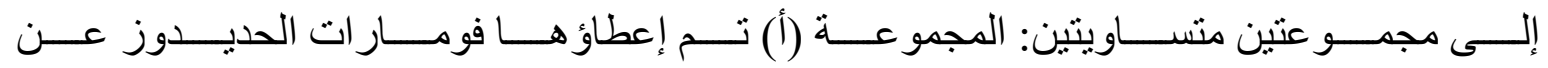

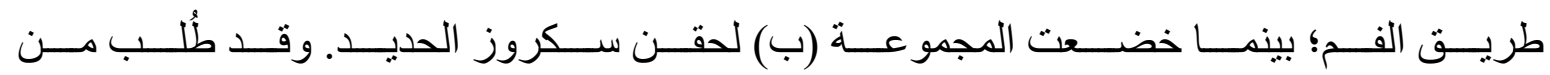

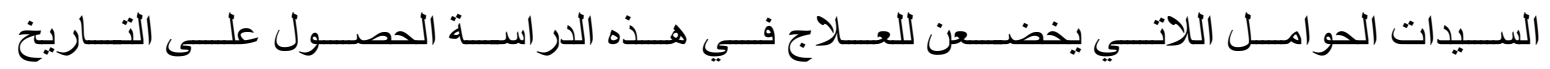

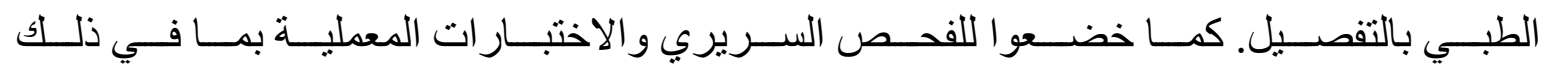
صورة دم كاملة؛ وتم لاحقاً إعطاء العلاج. 


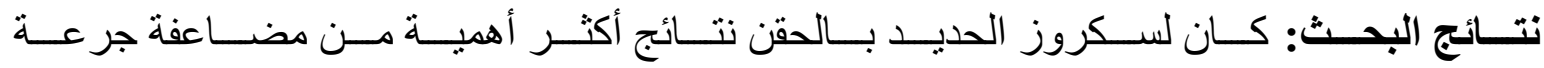

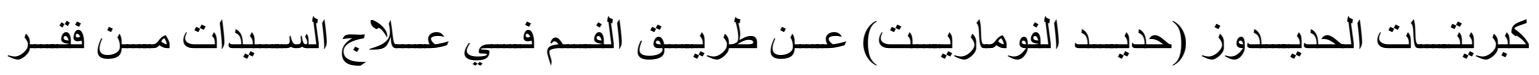

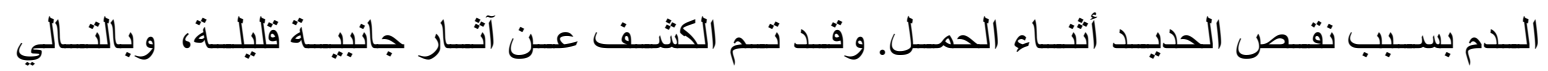

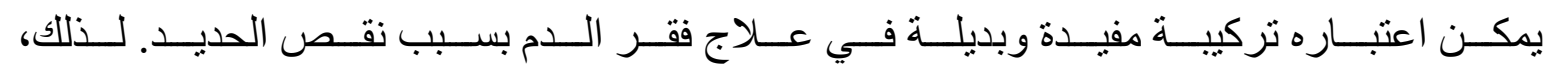

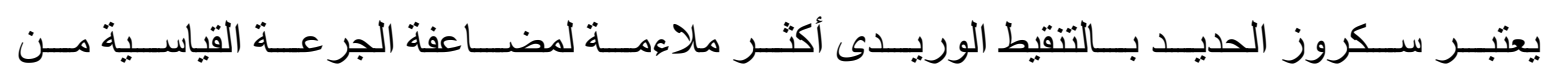

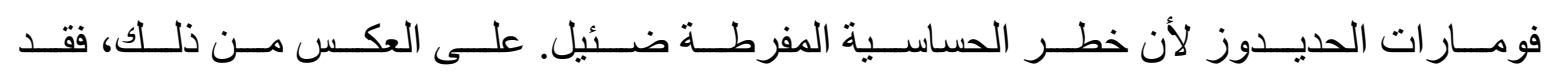

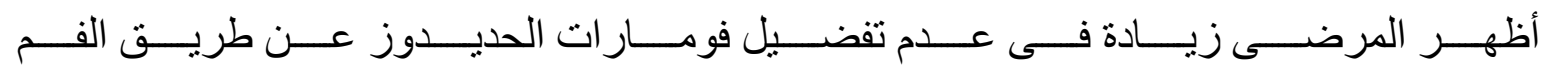

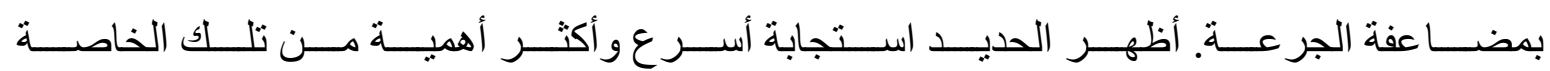

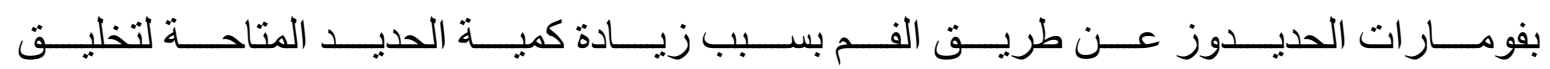
الهيموجلوبين في نخاع العظام عند علاج السيدات باستخدام العلاج بالحديدوز.

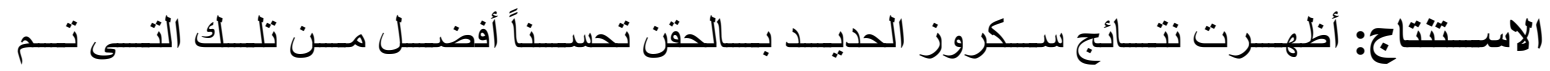

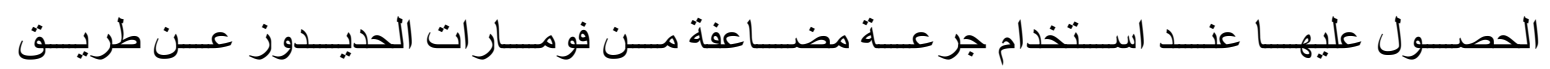

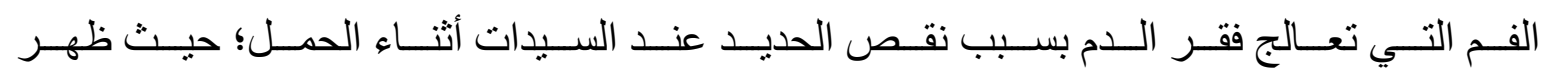

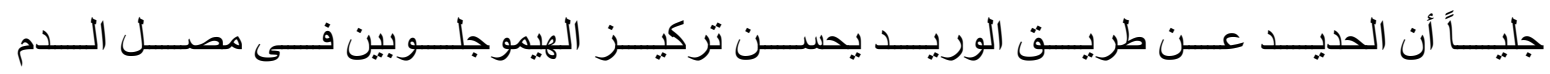
الفيريتين بصورة أكبر من العلاج بفومار ات الحديدوز عن طريق الفم.

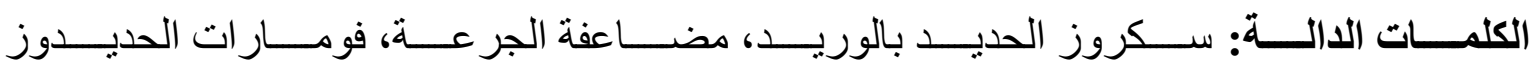
بالفم، علاج أنيميا نقص الحديد، الحمل. 